栄養と食到 Vol. 25 No. 5 369〜375 1972

報文

\title{
電子線照射によるかまぼこの貯蔵
}

\author{
北 村 禎 三*, 上野 照 雄** \\ * 大阪府立公臬衛生学院栄養部 \\ ** 大阪府立放射線中央研究所
}

\section{Preservation of Kamaboko by Electron Irradiation}

\author{
Teizo Kitamura*, Teruo Ueno** \\ * Department of Nutrition Science, Public Health School of Osaka Prefecture, \\ Sumiyoshi-ku, Osaka \\ ** Department of Applied Biology, Radiation Center of Osaka Prefecture, Sakai, Osaka
}

J. Jap. Soc. Food and Nutr., 25 (5), 369 375 (1972)

The effect of electron irradiation on the preservation of steamed kamaboko (a kind of fish paste products) was studied over a range of doses from 300 to 1,000 krads. The steamed kamaboko used in the study contained $0.2 \mathrm{mg}$ furylfuramide [2-(2-furyl)-3-(5-nitro-2-furyl)-acrylamide] per $\mathrm{kg}$ of the food as a food preservative. Steamed kamaboko was packed with cellophane and irradiated by a $5 \mathrm{MeV}$ electrons from a linear accelerator at room temperature. The maximum ionization density in steamed kamaboko treated with the above electrons was observed at a depth of $7 \mathrm{~mm}$ from the surface. There. fore, it seemed that the electron irradiation by an energy of $5 \mathrm{MeV}$ was suitable for sterilizing the surface.

From the results of organoleptic tests (ordor, discoloration, mucilage and mould), and of determinations of bacterial number and acidity, $500 \mathrm{krad}$ was selected as a suitable dose for the food preservation.

Retardation of spoilage and prolongation of storage life were observed on the irradiated kamaboko; the storage lives of the unirradiated one were 10 days at $8^{\circ} \mathrm{C}, 5$ days at $20^{\circ} \mathrm{C}$ and 2 days at $28^{\circ} \mathrm{C}$, but in the case of irradiation 25 days at $8^{\circ} \mathrm{C}, 10$ days at $20^{\circ} \mathrm{C}$ and 4 days at $28^{\circ} \mathrm{C}$, respectively.

(Received December 16, 1971)

わが国における食品の放射線照射，すなわち食品照射 はまだ実用の段階に至っていないか，新しい食品眝藏法 として食品工業上注目されている。食品照射について は，放射線に上る殺菌作用のほか，放射線に上る食品成 分の変化, さらに照射食品の安全性の問題についても研 究が進められている゙。

これまでの水産ねり慗品の放射線貯藏に関する研究は

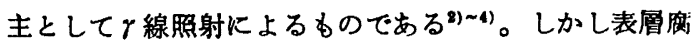
敗をする食品に対して, 放射線による食品成分の变化を できるだけ少なくし，かつ表屡殺菌の効果をあげるため には，r線よりもしろ透過力の弱い龟子線による照射が
有效であると考えられる。

したがって水産ねり整品特有の風味をできるだけ保持 しなから表層殺菌を実施する目的で，蒸しかまほこに適 した線量の電子線を照射し，成分変化ならびに眝蔵性に ついて檢討したのでその結果を報告する。

\section{実 験 少 法}

1. 㲷 料

市販の蒸しかまはこを用いた。蒸しかまはここはセロフ ケン紙で上部を簡単に被覆してあったので, 微生物によ る二次污染と試料の乾燥を防ぐために殺菌したセロ？ 
ン紙で二重に包装した。試料の表面より内側に5 mmない し $7 \mathrm{~mm}$ までの層を外部，それょり内側の部分を内部と 称した。な打試料 $1 \mathrm{~kg}$ 当たり，食品保存料として $0.2 \mathrm{mg}$ のフリルフラマイド [2-(2-furyl)-3-(5-nitro-2-furyl) acrylamide]が添加されていた。

\section{2. 照射およひ貯蔵条件}

大阪府立放射線中央研究所の線型加速器を用い, 七口 ファン林て重包装した上記実験試料に $5 \mathrm{MeV}$ の電子線 を室温で照射した。試料の密度が水と等価と仮定し試料 のごく表面における吸収線量が $300 \mathrm{krad} か ら 1,000 \mathrm{krad}$ までとなるように照射を行なった。吸収線量の算出は次 式にしたがった。

$\mathrm{D}=\mathrm{S} \cdot \mathrm{i} \cdot \mathrm{t} / \mathrm{x} \cdot \mathrm{y} \times 10^{5} \mathrm{rad}$

ただし，D：試料の吸収線量

$\mathrm{S}$ : 阻止能 $(\mathrm{dE} / \mathrm{dx}) 5 \mathrm{MeV}$ の場合は $2.0 \mathrm{MeV} / \mathrm{g} / \mathrm{cm}^{2} \quad \mathrm{E}:$ 照射エネルギー i : 電流 $(\mu \mathrm{A})$

$\mathrm{t}:$ 照射時間（秒）

$\mathrm{x}:$ 試料が 1 秒間に移動する距離 $(\mathrm{cm})$

$\mathrm{y}$ : 電子線のスキャン幅 $(30 \mathrm{~cm})$

この条件で照射した場合, 試料の温度上䄯扰よび放射 化は認められなかった。このように照射した試料（照射 試料) と非照射試料を $28^{\circ} \mathrm{C} て 78 \%$ 湿度の恒温器内で 1 週間眝藏した。な扰 $8^{\circ} \mathrm{C}, 20^{\circ} \mathrm{C}$ の各温度における貯藏 状況についても検討した。

\section{3. 還元糖の定量}

還元糖はフェーリングレーマンショール 法(5) で定量 し,ブドウ糖値として示した。この場合, 試料 $5 \mathrm{~g}$ を磨 啸し, 蒸溜水で $100 \mathrm{~m} l$ になるよ 5 に調整した試料液を用 いた。蔗糖を定量する際は, この試料液 $50 \mathrm{~m} l$ に $0.1 \mathrm{~N}$ 塩酸 $15 \mathrm{ml}$ を加兄, 沸騰水中で 30 分間, 加水分解し中和 した後，転化糖量を測定し蔗糖量を算出した。濒粉の定 量の際は, 試料夜 $100 \mathrm{ml}$ に $25 \% \mathrm{HCl} 10 \mathrm{ml}$ を加え沸 騰水上で 150 分間, 加水分解し中和した後, 全還元糖量 を測定し，それょり遊離還元糖量および転化糖量を差引

\section{き，澱粉量を算出した。}

\section{4. 室素の定量}

窒素はミクロケルダール法で定量した。試料 $10 \mathrm{~g}$ に蒸 溜水 $20 \mathrm{~m} l$ を加えて磨啸した後, それを 10,000 r.p.m. 10分間遠沈し，その上清に $30 \%$ 三塩化酢酸を加えて生ず る沈殿の窒素量を水溶性たん白態窒素量, その上清の窒 索量を水溶性非九ん白態窒素量とした。

\section{5. 一般生菌数}

二重平板培養法で計測した。試料 $10 \mathrm{~g}$ に減菌生理食塩 水 $20 \mathrm{ml}$ を加えて磨碀した後, 1,500 r.p.m. で 1 分間遠 沈し，その上清を菌液とした。この菌液を生理食塩水で 10倍段階稀釈を行ない，その $1 \mathrm{~m} l$ をぺトリ皿に入れ，一
般細菌用標準寒天培地（日水製）の約 $15 \mathrm{ml}$ と混积し放 冷した。この平板に小量の同培地を重層して, $37^{\circ} \mathrm{C}, 48$ 時間培養し, 全集落を計測し, 試料 $1 \mathrm{~g}$ 中の生菌数を算 出した。

\section{6. 滴定酸度}

試料 $5 \mathrm{~g}$ に蒸溜水 $100 \mathrm{~m} l$ を加え, 磨啸した後, それ

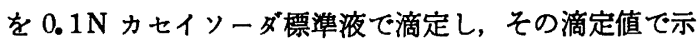
した。

\section{7. かたさ}

試料のかたさを $\mathrm{N} \cdot \mathrm{G} \cdot \mathrm{K}$ 型カードメーター（飯尾電機 贸）を用いて測定した。カードメーターのバネ部下端に $200 \mathrm{~g}$ の分銅を付け，さらにその先端にある感圧円板部 に $5 \mathrm{~mm} \times 0.5 \mathrm{~mm}$ の針を固定した。試料を厚さ $10 \mathrm{~mm}$ の輪切りにし，ピン全体が試料の切断面部に貫入するに 要する荷重を測定した。測定は試料の内外部について各 ヶ 6 回実施し，その平均值をかたさとした。

\section{8. 官能検查}

照射直後扰よび各温度て眝藏した試料について，一定 期間ごとに, 臭い扰よび外観（变色, 粘質物およびかび の発生）を調べた。

\section{9. 試料内部の吸収線量の測定}

コバルトガラス線量計 $(\mathrm{BL}-\mathrm{Co}-1.5,15 \times 6 \times 1.5 \mathrm{~mm}$, Bausch-Lomb 社製）を用いて試料内部に吸収された電 子線の吸収線量を測定した。そのためまず試料の表面が 水平になるよ 5 に整形し, 線量計を試料表面に平行にな るように試料内に挿入した。この試料に加速エネルギー $5 \mathrm{MeV}$, 吸収線量 $500 \mathrm{krad}$ 一水の電子線を照射した後, 試料内より变色した線量計を取りだし，水,エタノール, エーテル，アセトンで洗條し風乾して，400 $\mathrm{m} \mu$ の波長 て吸収線量を比色定量した。検量線は各種線量の電子線 を線量計に直接照射して作成した。

\section{実 験 結 果}

\section{1. 非照射試料の噟敗状況}

まず非照射試料を分析すると，3.3\%の澱粉， $3.5 \%$ の 蔗糖, $1.6 \%$ の旅離還元糖が含まれていた。したがって 試料は加糖かまほこであるといえる。

この非照射試料を $28^{\circ} \mathrm{C}$ て眝藏して，その内外部の一 般生菌数を観察した（図 1)。眝藏直前の試料中の菌数は 内外部之も, 比較的少ないが，試料外部の菌数が内部よ クやや多い。しかし貯蔵の期間が長くなるにつれ，内外 部の菌数は漸次增加し，とくに眝蔵24時間目より，外部 の菌数は著しく増加した。したがって, 試料は $28^{\circ} \mathrm{C}$ 詝 藏では著しい表層腐敗によって劣化すると考えられる。

\section{2. 試料内各部の線量分布}

電子線の上5に透過力の弱い荷電粒子を充分厚い、物体 に照射すると，入射粒子の全エネギーは物体に吸収され 
Vol. 25 No. 51972

Table 1. Effects of electron irradiation with various doses on the odor and coloring of kamaboko

\begin{tabular}{lrrrrrrrc}
\hline Dose krad & 0 & 300 & 400 & 500 & 600 & 700 & 800 & 1,000 \\
\hline Irradiating odor & - & \pm & \pm & \pm & + & ++ & +++ & ++++ \\
Coloration in the inner part & - & - & - & - & - & \pm & \pm & \pm \\
\hline \hline
\end{tabular}

,,- \pm+ , or, ++++ : Not, Slight, Strong or Very strong

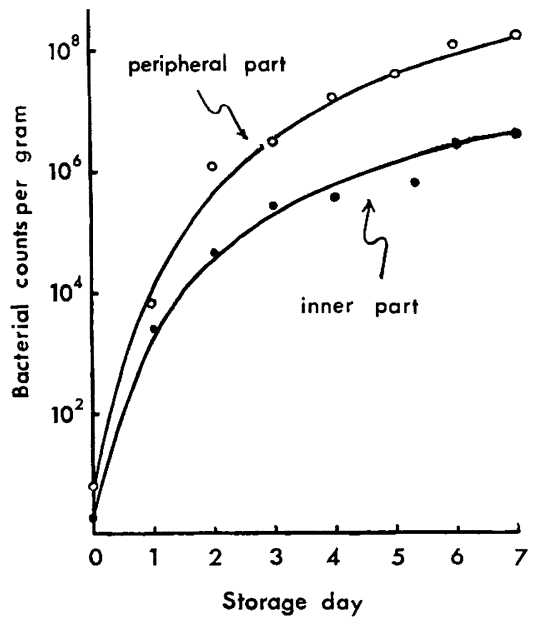

Fig. 1. Changes in total bacterial counts of unirradiated kamaboko stored at $28^{\circ} \mathrm{C}$.

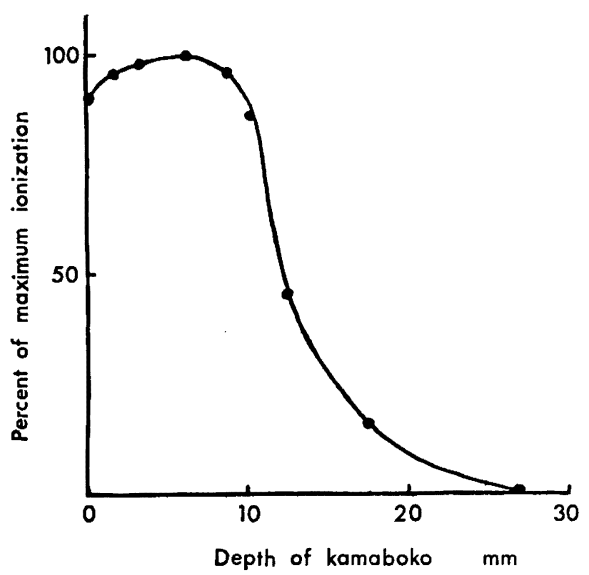

Fig. 2. Distribution of ionization density in kamaboko by $5 \mathrm{MeV}$ electrons.

$ろ^{6)}$ 。そこで試料に，5 MeV, 吸収線量 $500 \mathrm{krad}$ 一水の 電子線を照射して，試料内部に扣ける吸収線量の分布を 測定した (困 2 )。試料の厚さは $27 \mathrm{~mm}$ ないし30 mm で あるか，表面より内側に $7 \mathrm{~mm}$ の部位が最大の吸収線量 を示し，10 mm 以上になると吸収線量は急激に減少し た。27 mmの部位には電子線はまったく達しなかった。 このようなことより $5 \mathrm{MeV}$ のエネルギーをるつ電子線 は表同照射に適するすのと考えられた。

\section{3. 適正線望の選定}

1）照射臭扣よび変色 試料に 300 ないし1, $000 \mathrm{krad}$ の電子線を照射し, 照射臭発生の有無, 变色状況を観察 した（表 1)。500 krad 以下の照射では，照射白ははと

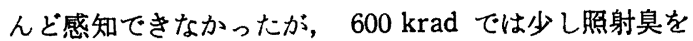
感じ, $700 \mathrm{krad}$ 以上では著しい照射臭を感じた。600 $\mathrm{krad}$ 以下では試料の変色は钼察できなかったが，700 $\mathrm{krad}$ 以上とくに $1,000 \mathrm{krad}$ では試料の外部に顕著な褐 変化が認められた。かまぼこは生食する食品であるの で，とくに外㘥，香気が重要視されている。したがって 照射による品質劣化を起こさない $500 \mathrm{krad}$ 以下の線量 が適切と考えられた。

2）一般生菌数 試料に 300 ないし 1,000 krad を照 射し, 直ちにその試料を貯藏して, 一般生菌数を計測し た（図 3-a, 3-b)。ただしこの場合，試料の内外部の区 別なく，試料全体を採取してその生菌数を計測した。

非照射試料を眝蔵すると，その生菌数は著しく增加し た。一方照射試料を眝蔵した場合, 照射に上る殺菌効果 あるいは菌增殖の抑制効果は眝藏の初期に現われた。貯

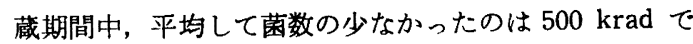
照射した試料であった。

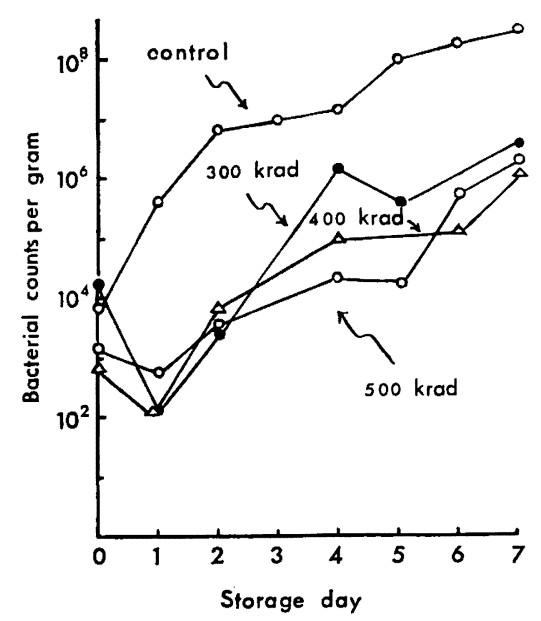

Fig. 3-a. Changes in total bacterial counts of kamaboko stored at $28^{\circ} \mathrm{C}$ after the irr. adiation of electrons at various doses. 


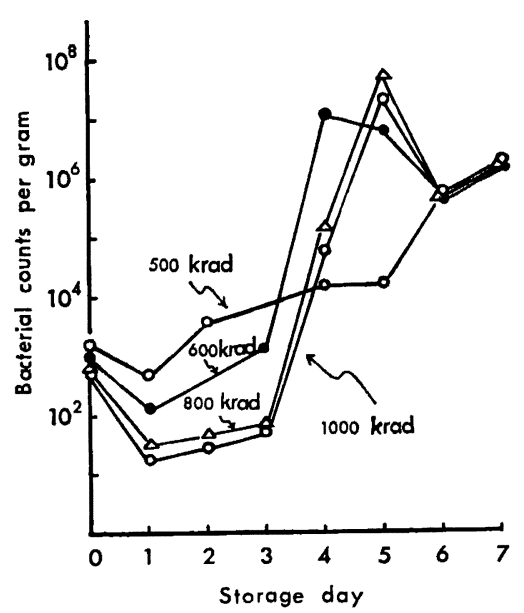

Fig. 3-b. Changes in total bacterial counts of kamaboko stored at $28^{\circ} \mathrm{C}$ after the irradiation of electrons at various doses.

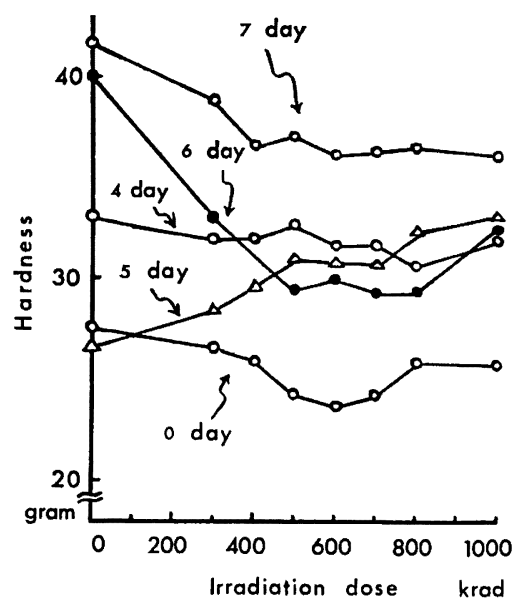

Fig. 5. Changes in hardness of peripheral part of kamaboko stored at $28^{\circ} \mathrm{C}$ after the irradiation of electrons at various doses.

3）滴定酸度 試料の腐敗状況を知る一指標として, 照射直後および 4 日間， 6 日間詝蔵した試料とくにその 外部の滴定酸度を測定した（因 4 ）。非照射試料を眝蔵 すると，その酸度は著しく上界した。しかし照射試料の 場合，その酸度上䄯はきわめて少なかった。とくに 400 $\mathrm{krad}$ 以上で照射すると, その試料の酸度は上萛せず, 新 鮮時の試料とほほ同一値を示した。

4）かたさ 照射および貯蔵によって, 試料のかたさ が変化するすのと推察し， とくに試料の外部のかたさを 測定した（図 5 )。照射によって試料が柔軟になること

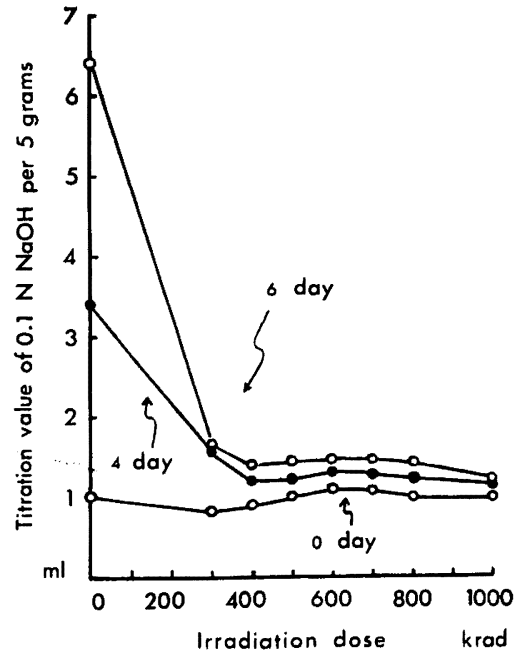

Fig. 4. Changes in acidity of peripheral part of kamaboko stored at $28^{\circ} \mathrm{C}$ after the irradiation of electrons at various doses.

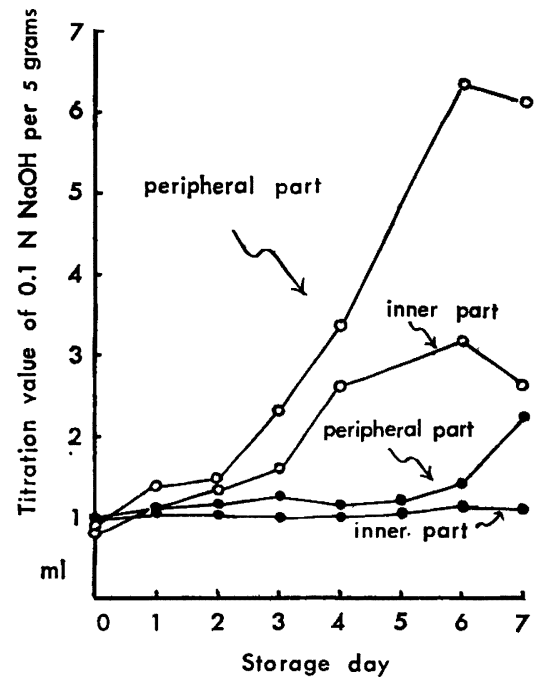

Fig. 6. Changes in acidity of kamaboko irradi. ated at a dose of $500 \mathrm{krad}$ by electrons and unirradiated kamaboko stored at $28^{\circ} \mathrm{C}$.

๑ : irradiated, 0 : unirradiated

が認められた。また貯蔵すると試料はかたくなる傾向が あったが， $500 \mathrm{krad}$ 以上で照射すると，貯藏による試 料のかたさの変動は比較的少なくなった。

5）線量の決定 以上の結果から, 照射によって試料

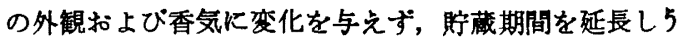
る線量として $500 \mathrm{krad}$ が最す適当であると思われた。 以後の貯藏実験ではこの線直を用いることにした。

4. $500 \mathrm{krad}$ 照射試料における锗変化

1）試料内外部の漓定酸度 $500 \mathrm{krad}$ 照射試料 と非 照射試料を眝䓲し, 両試料の内外部の滴定醊度の変化を 


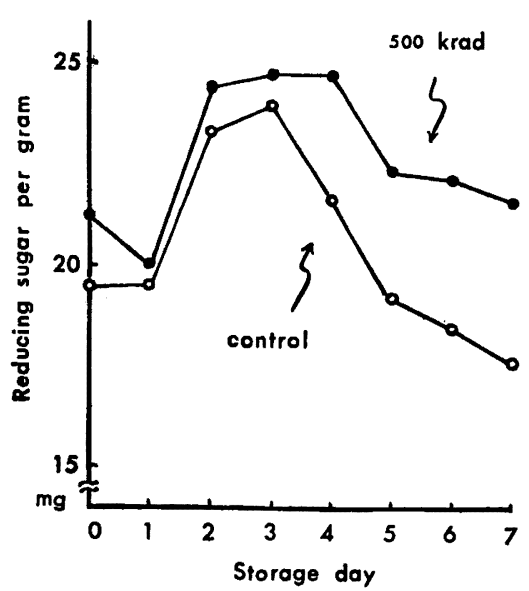

Fig. 7. Changes in reducing sugar of kamaboko stored at $28^{\circ} \mathrm{C}$ after the irradiation of electrons at $500 \mathrm{krad}$.

- : irradiated, $O$ : unirradiated

調べ，腐敗状況を検討した（図 6 )。非照射試料の内外 部の酸度は，貯藏期間が長くなるにつれて上䄯した。と くに外部の酸度は内部の值より高く, 酸度変化よりみて す試料が表層腐敗して劣化することがわかる。

一方, 眝藏中にみられる照射試料の酸度は眝蔵前（新 鲜時) の酸度とおお拈むね同じであった。したがって 500 krad 照射によって腐敗を抑制し，貯蔵期間を延長する 効果が認められた。

2）還元糖 照射試料を眝蔵し, 試料中の還元糖量を 测定した（図 7)。照射すると試料中の還元糖量は增加し た。また貯蔵中, 両試料の還元糖量は眝藏 3 日目ないし 4 日目で最高となり, 以後減少した。

3）水溶珄窒素化合物 照射に上る成分変化を検討す るために，照射試料を貯藏し，水溶性たん白態窒素量お

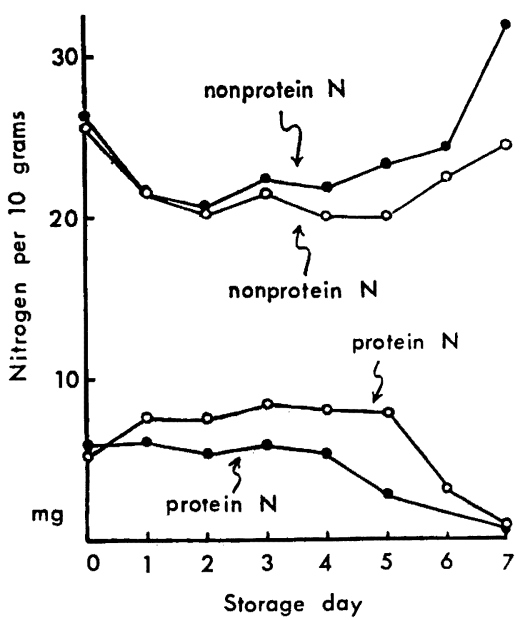

Fig. 8. Changes in water soluble nitrogenous compounds of kamaboko stored at $28^{\circ} \mathrm{C}$ after the irradiation of electrons at 500 krad.

๑ : irradiated, $O$ : unirradiated

よび皮溶性非たん白態窒素量を測定した（図 8 )。眝蔵 中, 照射試料の水溶性非たん白態窒素量は非照射試料の 値より高く, 水溶性たん白態窒素量については, 逆に非 照射試料の值より低いことが明らかとなった。

4）外観扣よび官能検査 $500 \mathrm{krad}$ 照射直後の試料 を非照射の新鮮試料と比較すると外観的には何ら相違は 認められなかった（表 2 )。しかし両試料を $28^{\circ} \mathrm{C}$ て眝蔵 すると, 試料の臭い, 試料表面に発生するかび, 粘質物 および褐色斑点の状況に相違があった。

i） 臭い 非照射試料を貯蔵すると，2 日目まで，新 鮮時と同じ香気を保っていたが，3日目より徐々に腐敗 臭を放ち，5 日目より非常に強い酸味臭を呈した。一方 照射試料の場合，4 日目まで香気を保っていたが，5 日 目より照射臭が感じられ，6 日目より劣悪な魚臭を発生

Table 2. Effects of electron irradiation on the spoilage of kamaboko stored at $28^{\circ} \mathrm{C}$

\begin{tabular}{|c|c|c|c|c|c|c|c|c|}
\hline \multirow{2}{*}{ Days stored } & \multicolumn{4}{|c|}{ Unirradiated } & \multicolumn{4}{|c|}{ Irradiated $500 \mathrm{krad}$} \\
\hline & Odor & Mucilage & Mould & Brown spot & Odor & Mucilage & Mould & Brown spot \\
\hline 0 & good & - & - & - & good & - & - & - \\
\hline 1 & fair & \pm & - & - & good & - & - & - \\
\hline 2 & fair & + & \pm & - & good & - & - & - \\
\hline 3 & poor & ++ & + & - & fair & \pm & - & - \\
\hline 4 & poor & +++ & + & + & fair & + & - & - \\
\hline 5 & very poor, acidy & +++ & +++ & + & poor & $+t$ & + & - \\
\hline 6 & very poor, acidy & ++++ & +++ & + & very poor, $f i$ & shy +++ & + & - \\
\hline 7 & very poor, acidy & ++++ & +++ & ++ & very poor, fi & shy +++ & ++ & - \\
\hline
\end{tabular}

,,- \pm+ , or ++++ : Same as Table 1 . 
した。

ii）粘質物 非照射試料の場合, 貯蔵 1 日目上り, 透 明粘質物が試料表面に少し生じ，3 日目よりその量が多 くなった。照射試料の場合, 3 日目上り, 透明粘質物が 試料表面に少し認められた。

iii）かび 非照射試料の場合,かびは2 日目より発生 した。照射試料の場合は 5 日目より発生したが, 繁殖の 珵度は非照射試料よりはるかに小さかった。

iv）褐色斑点 非照射試料を聍蔵すると, 4 日目より 試料の外部に褐色の斑点が現われた。しかしこの斑点は 照射試料を貯藏した場合，現われなかった。

以上の観察結果より， $28^{\circ} \mathrm{C}$ て貯藏した非照射試料の 可食期間は眝藏 2 日間, $500 \mathrm{krad}$ 照射試料の場合は 4 日 間と考えられる。

5) 貯蔵温度との関係 $8^{\circ} \mathrm{C}, 20^{\circ} \mathrm{C}$ の各温度て貯蔵 し, 温度による眝蔵效果を可食期間の面より検討した。 可食期間は官能検査により判定した。 $20^{\circ} \mathrm{C}$ て貯蔵した 場合, 非照射試料の可食期間は 5 日間, 照射試料の場合 は10日間であった。 $8^{\circ} \mathrm{C} て ゙$ 眝藏した場合, 非照射試料の 可食期間は 10 日間，照射試料の場合は25日間であった。 眝蔵温度を低くすると，照射の効果が貯蔵期間の延長と なって現われたが，長期拧蔵の慗害として試料の乾燥は 避けられなかった。

\section{考察}

試料に用いた蒸しかまほここはリルフラマイド $(0.2$ $\mathrm{mg} / \mathrm{kg}$ 試料）を含む加糖かまぼこであるが，貯蔵する と木俣》が指摘している加糖かまほこ型表層腐敗をして 悪変した。したがって,この試料に電子線を照射し表層 殺菌を試みた。照射による試料の放射化を避けるため 10 $\mathrm{MeV}$ 以下の電子線の使用が 勧められているが，英国で 推奖されている $5 \mathrm{MeV}^{1)}$ で照射した。この場合，大部 分の電子ェネルギーは試料表面下 $10 \mathrm{~mm}$ まで部分に 吸収された。試料の最高厚み部分は 27 ないし $30 \mathrm{~mm} て ゙$ あるので, $5 \mathrm{MeV}$ 電子線の照射はこの実験目的に適し ていた。

表層腐敗しやすくまた生食するといら試料の特性を考 慮して, 低線量照射 ${ }^{8}$ に上る通常腐敗菌の減少を目標と し, 官能検查, 一般生菌数および滴定酸度の測定結果よ り，500 krad を試料の適正線量と定めた。かまほこの 香気は品質上の重要な要素であるが， $600 \mathrm{krad}$ 照射で すでに品質劣化を示す照射臭を感知した。また照射臭の 発生のほか, 試料の褐変化は線量の增加に伴い激しくな り，貯蔵するに伴い強くなる傾向があった。

$600 \mathrm{krad}$ 以上で照射した試料を貯藏すると, 貯蔵の 初期において，菌数の顕著な減少が観察された。このよ らな現象は, フリルフラマイド容液で処理された魚肉塊
をっ線照射した際です認められており，食品保存料併用 による貯藏に対する相剩効果が指摘されているき。 フリ ルフラマイドの $0.5 \times 10^{-4} \mathrm{M}$ メタノール溶液を電子線照 射した場合, $500 \mathrm{krad}$ でのフリルフラマイド残存榇は84

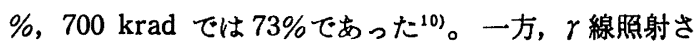
れた微生物はフリルフラマイドに対する抵抗性を失うこ とが知られている(1)。これらのことより,フリルフラマ イド添加試料を照射した場合にみられる眝蔵初期の菌数 の減少は照射と保存料併用による殺菌增感效果の現われ と推察される。

官能検査の結果, $500 \mathrm{krad}$ 照射による試料の品質劣 化はほとんど感知できなかった。しかし試料成分の放射 線による分解はこの低線量照射によっても観察された。 すなわち $500 \mathrm{krad}$ 照射によって邆元糖や水溶性非たん 白態窒素化合物が生成され, さらに食品組織が軟化し た。これらの現象は照射に上る殹粉の解重合と, それに

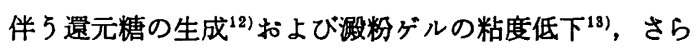
にたん白質の放射線分解 ${ }^{14)}$ に関連したすのと考えられ る。なお，照射によってンーセージか軟化し ${ }^{15)}$ ，また照 射肉を加工原料とした場合, 結着性が低下すること胡す すでに報告されている。

$500 \mathrm{krad}$ 照射によって，試料の香気を害することな く，細菌数の增加を抑制することができ，試料の貯藏期 間を延長することができた。この場合，低温で咛蔵する と,さらに貯蔵期間を延長することが可能であった。し かし長期貯蔵をすると, 試料が乾燥するので, その防止 が必要である。また $500 \mathrm{krad}$ 照射試料の安全性につい ては検討していないか，食品照射の実用化に際して, 重 要な課題であると思う。

\section{要約}

放射線照射による、フリルフラマイドを含む水産ねり 製品の表層殺菌を実施する目的で，蒸しかまほこに電子 線を照射して，その貯藏性を検討した。

（1）非照射の試料を $28^{\circ} \mathrm{C}$ で貯藏すると表層腐敗し た。すなわち貯藏 1 日目より試料表面に粘質物を生じ2 日目よりかび，3 日目より腐敗臭，4 日目より褐色斑点 が発生した。

（2）官能検查と一般生菌数および滴定酸度を測定し た結果より, 試料の通常腐敗菌の增殖を抑制し, 試料特 有の香気を保持しらる適正線量を $500 \mathrm{krad}$ と定めた。 $500 \mathrm{krad}$ て照射した試料を $28^{\circ} \mathrm{C}$ て眝蔵すると， 3 日目 より粘質物が生じ，5 日目よりかびおよび腐敗臭が発生 した。しかし褐色斑点は生じなかった。

（3）官能検查（臭いおよび变色）の結果では， 500 $\mathrm{krad}$ で照射した直後の試料は非照射試料と区別するこ とができなかった。しかし照射によって，還元糖および 
水溶性非たん白空素化合物の生成, 食品組較の化が観 察された。

（4） $500 \mathrm{krad}$ 照射によって，試料の可食期間を延 長することが可能であった。その延長日数は $28^{\circ} \mathrm{C}$ の貯 藏で 2 日， $20^{\circ} \mathrm{C} て ゙ 5$ 日， $8{ }^{\circ} \mathrm{C}$ て15日であり，食品に対 する照射効果は低温眝蔵ほど，顕著に現われた。

終わりに臨み，電子線照射に御協力いただいた大阪府 立放射線中央研究所の小島撜部長，線源課の諸氏に深謝 いたします。また御指尊いただいた大阪府立公衆衛生学 院の八木明院長, ならびに実験に協力された西村早苗, 谷野真澄，野口絹子の諸㜔に謝意を表わします。

\section{文献}

1）科学技術庁編：わが国における食品照射の現状 と問題点, (1967)

2）岡田郁之助, 小坂部勇, 菊地武昭, 福島 清, 山 下久雄, 佐々木正五, 橋本一男, 赤塚 盛, 渡 辺 涉：日水誌, 20, 989 (1955)
3）浦上智子, 今井登美子：栄盖と食糧, 10, 145 (1957)

4）浦上智子，今井登美子：栄湌と食糧， $11 ， 78$ (1958)

5）東大農芸化学教室編：実験農芸化学下， 638 (1966), 朝倉書店 (東京)

6) Trump, J. G. and Van de Graaff, R. J.: J. Appl. Phys., 19, 599 (1948)

7) Kimata, M.: Memoirs Coll. Agr. Kyoto Univ., 59, 68 (1951)

8）藤巻正生：食衛誌，9，337（1968）

9）河端俊治, 小骖秩夫, 興津知明 : 食品照射, 3, 31 (1968)

10）上野照婎, 北村禎三：未発表

11）岡沢精茂，横島邦彦，松山晃：日本農化大会 講演集, 76 (1970)

12) Wolfrom, M. L.: Adv. in Carbohydrate Chem., 16, 36 (1961)

13) Saini, V.: J. Food Sci., 33, 136 (1968)

14) Liuzzo, J. A., Lagarde, S. C. and Novak, A. F.: J. Agr. Food Chem., 17, 764 (1969)

15) Coleby, B.: J. Sci. Food Agr., 13, 628 (1962)

16）平野正男：食品照射，5，94（1970）

（昭和46年12月16日受理） 